\title{
The application of Urban Health Equity Assessment and Response Tool to assess health inequity among dwellers of an urban slum area in Giza Governorate, Egypt
}

\author{
Mohsen Gadallah ${ }^{1}$, Soad A. Megid ${ }^{2}$, Samir Refaey', Moustafa El-Hussinie ${ }^{1}$, Amira \\ Mohsen ${ }^{3}$,Mohammad A. Ardakani', Samar El-Feky ${ }^{4}$ \\ ${ }^{1}$ Department of Community Medicine, Faculty of Medicine, Ain Shams University, Cairo - \\ Egypt \\ ${ }^{2}$ Ministry of Health and Population \\ ${ }^{3}$ Department of Community Medicine, National Research Centre, Cairo, Egypt \\ ${ }^{4}$ Community-Based Initiatives (CBI), WHO/EMRO
}

\begin{abstract}
Background: The WHO in 2008 developed the Urban Health Equity Assessment and Response Tool. It is a user-friendly guide for stakeholders and decision makers at national and local levels to identify health inequities. Moreover, using such tool will facilitate decisions on viable and effective strategies, interventions, and actions that should be used to reduce health inequities.

Aim: To assess the health equity in a disadvantaged district (Gezerit El Warak) located in Giza province, Egypt.

Materials and Methods: A population-based survey was conducted in the study district. A total of 643 heads of households were interviewed using Urban Health Equity Assessment and Response developed by WHO. Indicators of key health outcomes and major social determinants were calculated and then compared with the corresponding national indicators. Results: The results of social determinants of health showed lower performance than national figures in the core indicators illiteracy (42.5\%) and male tobacco smoking $(56.0 \%)$, whereas good performance was reported for unemployment among adults $(2.0 \%)$, fully immunized infants $(95.1 \%)$, and females' overweight $(34.5 \%)$ /obesity (38.0\%). The main problem encountered was the inadequate physical infrastructure, mainly safe drinking water and sewage disposal system. The health outcome indicators revealed higher prevalence of hypertension among both males (20.7\%) and females (19.2\%). History of diabetes mellitus was markedly higher than the national figures among both males (11.5\%) or females $(9.6 \%)$. Conclusion: Compared with the national indicators, the main health determinants with low performance encountered in the study area included the physical infrastructure and high prevalence of male tobacco smoking. Health outcome indicators with low performance were diabetes and hypertension. The response of stakeholders was positive and immediate actions were taken to tackle some of the low-performance indicators.
\end{abstract}

Received: 4 February 2017, Accepted: 29 July 2017

Key Words: disadvantaged areas, Egypt, health determinants, health inequity, social determinants, underprivileged areas, urban slum .

Corresponding Author: Mohsen Gadallah, MD, Department of Community Medicine, Faculty of Medicine, Ain Shams University,, Tel.: 0020224346888, E-mail: e-mail: mohsengadallah@gmail.com

ISSN: 0013-2446, Vol. 92, No.2

\section{INTRODUCTION}

Urban population is expected to grow to 4.9 billion by 2030 , with the most rapid growth occurring in the urbanized areas of Africa and $\mathrm{Asia}^{[1]}$. Slums and squatters constitute $\sim 20 \%$ of all households ${ }^{[2]}$. The definition of a 'slum' is still a controversial issue, and there are many definitions of slums. The majority of slums share in common a lack of basic urban services, including clean water, improved sanitation, and insecure residential status ${ }^{[3]}$.

In Egypt, slum areas are increasing especially in Cairo and Giza governorates; their exact proportion is not accurately estimated owing to many definitions for slum. Operational definition used by municipal authorities to define slum is 'Residential areas characterized by being developed in contradiction to planning and building laws and regulations in the absence of state's supervision ${ }^{[3]}$. The research studies in Egypt for health assessment of slum dwellings are scares: some are related to child health ${ }^{[4]}$, whereas others are related to maternal health ${ }^{[5,6]}$. Most urban residents in sub-Saharan Africa live in slums often characterized by a lack of basic services such as water and sewerage. In the Langos slum area located in Eldoret town, 
Kenya, most people (91\%) used wells as the main source of domestic water, whereas the rest used tap water ${ }^{[7]}$. In India, a pilot cross-sectional study was performed in four urban slums of South Delhi, and it showed that $75 \%$ of the participants did not use any method for treatment of drinking water and $45 \%$ consumed water from privately owned tube well/bore well ${ }^{[8]}$.

Slum upgrading, at its basic level, involves improving the physical environment of the existing area, such as improving and installing basic infrastructure like water, sanitation, solid waste disposal, electricity, access roads, and footpaths, as well as home improvement and securing land tenure ${ }^{[9]}$

The Urban Health Equity Assessment and Response Tool (Urban HEART) was developed by the WHO to equip policy makers with the necessary evidence and strategies to reduce intercity and intracity health inequities ${ }^{[10]}$.

The adoption and use of Urban HEART by national and local governments, community organizations, and urbanized or rapidly urbanizing communities are intended to guide policy makers and key stakeholders to achieve a better understanding of the social determinants of health and their consequences for people living in urban areas, stimulate them to make strategic decisions and prioritize specific actions and interventions that are tailored to the needs of vulnerable and disadvantaged groups in the urban areas, and support program managers in improving intersectoral collaboration and communication strategies related to the social determinants of health. Despite the attempts of the Egyptian government to limit informal urban growth, the expansion of informal settlements continues. According to the 2006 census, it was estimated that $60 \%$ of Egypt's urban population was living in unplanned settlements. In Giza Governorate, there are both urban and rural areas. People who lived in agricultural land changed their lifestyle characteristics by building houses for their own use or selling their lands to others as construction land, which is an illegal act. Accordingly, many unplanned residential areas or 'Ashwa'iyyat' in Arabic language - were created. One of the districts affiliated to Giza governorate is El Warak district, in which Gezerit El Warak is located. Gezerit El Warak is considered an unplanned residential slum area on the River Nile with no access to motorized public transport. The total population is around $20000-35500$ inhabitants but there is no accurate figure for the total population. Gezerit El Warak in the past was an agricultural area; however, in recent times, most of the inhabitants are working in freelancer work or other jobs in the government, especially young adult population. According to our best knowledge, there were no research studies conducted in this area.

The main objectives of this study were to assess the most common health determinants that affect the health of the population living in Gezerit El Warak, as one of the disadvantaged places in Giza city; to compare the social determinants of Gezerit El Warak with the national standards to pinpoint the gap in health equity; and to come out with appropriate and practical responses to reduce health inequities through inter-sectoral action and community engagement.

\section{MATERIALS AND METHODS}

\section{Study design}

This is a cross-sectional population-based study based on household survey. The study population was the head of the households.

\section{Selection of the research site}

Gezerit El Warak affiliated to Giza governorate was selected owing to its location as unplanned residential slum area in the river Nile, with no access to public transportation and other needed social services. It has extremely narrow lanes and streets that do not allow any private cars and public transportation buses to move inside this island, and no other means of transportation after 8 p.m., as the only two boats (one private and the other is public) finish their working hours at 8 p.m. This makes life difficult for those in emergencies who may need to get to a hospital quickly.

\section{Stakeholders' awareness}

An orientation workshop was organized to brief the stakeholders about Urban HEART concept and methodology in Gezerit El Warak. The workshop was held in a hotel in Giza and attended by participants representing the Ministry of Health and Population (MOHP); members of the local Council of Gezerit El Warak; different sectors of the Giza Governorate, such as Health, Environment, Agriculture, Education, Local Development, and Social Solidarity; nongovernmental organizations (NGOs); focal point of community-based initiative at MOHP; and WHO's Representative Office, Egypt.

\section{Stakeholders’ response}

To complete the cycle of urban HEART, the Ministry of Health and Population in collaboration with the WHO country office organized a workshop participated by the city authorities, local community, and representatives from NGOs to share the results of equity assessment in Gezerit El Warak and come out with possible responses to tackle inequities.

\section{Involvement of local community}

A meeting with youth volunteers nominated by the head of Youth Associate of Gezerit El Warak was held at MOHP to discuss the objectives and methodology of the 
study. The youth volunteers agreed to provide the research team with the geographical characteristics of Gezerit El Warak and the distribution of the residential areas in the study site using a map of the area. In addition, the youths volunteered to help the field team during surveying the houses. Discussions were carried out about the importance of involvement of the members of local community in the process of study and sustainability of the project.

\section{Tool of the study}

The Urban HEART that had been developed by the WHO centre for Health Development, Kobe (Japan $)^{[10]}$ was adopted based on the local context and needs. A questionnaire was designed to collect data related to the study indicators (key health outcomes and key social determinants of health). According to the guidelines of Urban HEART, health outcome indicators were further divided into summary indicators (infant and neonatal mortality rates, which obtained from MOHP records) and disease-specific morbidity (hypertension and diabetes mellitus). Social determinants of health have been categorized into four domains: physical environment and infrastructure, social and human development (which include smoking and overweight/obesity), economics, and governance (spouse participation in the last referendum). Regarding governance, when the respondent was wife, we asked about her participation in the last referendum and then we asked her about her husband's participation, and vice versa when the respondent was the husband.

\section{Sampling and sample size}

The study population was the head of the households. Many key indicators were used for calculating the sample size. These included the prevalence rates of smoking, hypertension, diabetes mellitus, immunization coverage, and illiteracy rate. For each indicator, a sample size was calculated and then we used the one that yielded the largest sample. The formula used included sample design effect $(=1.5)$ and the anticipatory rate of nonresponse $(10 \%)$ and the lowest prevalence rate (according to the information provided from the health affairs in Giza/MOHP, the prevalence of hypertension was 17\%). The confidence level was set as $95 \%$. A sample of 616 households was obtained. We decided to increase the sample to 660 households to overcome any incomplete data in the questionnaires.

The study district was divided geographically into seven residential segments. A landmark was identified for each segment and then the field investigators moved in clockwise direction to visit each household until reaching the sample size required (equal sample from each segment).

Four teams attended 1-day training workshop for data collection with emphasis on the objectives of the project and the techniques of interview and filling the questionnaire. Measuring the weight, height, and blood pressure was done. Each team consisted of a physician from the surveillance unit at MOHP and one of the youth volunteers as a guide for movement inside the Gezerit El Warak.

\section{Piloting and pretesting}

The questionnaire was field tested in the same area of the study to examine feasibility and accuracy of the questionnaire. In this pilot study, 30 households were interviewed and not included in the study sample. The results revealed that questions related to the piped water supply and safety of water for drinking need to be more detailed. Moreover, some points in health expenditure need to be clarified, that is, changing in the wording.

\section{Data collection}

A door-to-door household survey was conducted in July 2011. All questionnaires were reviewed by MOHP research team for verifications of data completion on a daily basis. All copies were submitted to the statistical team for data coding, entry, and cleaning.

BMI of the adult respondent was calculated from height and weight and participants were classified accordingly into underweight (BMI <18.5), normal (BMI: 18.5-24.9), overweight (BMI: 25-29.9), and obese (BMI 30+). The mean systolic and diastolic blood pressures were calculated from two readings, and participants were classified as hypertensive if the systolic blood pressure of at least 140 or diastolic blood pressure of at least $90^{[11]}$. Smoking use was defined as self-reported current smoker of cigarette, shisha (water bubble), or both.

\section{Statistical analysis}

SPSS version 20 (IBM Corporation, Chigago - IL USA) was used in data cleaning and data analysis. For continuous data, descriptive analysis in the form of mean and SD was used to describe the data. For categorical qualitative data, descriptive analysis in the form of frequency tables, percent, and rates was calculated. Double data entry using SPSS data entry module version 4 (NY- USA) was done to ensure minimal data entry mistakes.

Two matrices were formulated, one (A) for health determinant indicators, whereas the second (B) for health outcome indicators. The red color cell indicates low performance of Gezerit El Warak with at least 20\% lower than the national indicator in The Demographic and Health Survey (DHS) survey, 2008. The yellow color cell indicates a slightly lower performance $(<20 \%)$, whereas the green color cell indicates the same or better performance.

\section{Research ethics}

This study was approved by the Research Ethics Committee of the Faculty of Medicine, Ain Shams University, Egypt. The questionnaire of the study was 
anonymous, and informed consent from each participant was taken after clear explanation of the purpose of the study.

\section{RESULTS}

Overall, 643 household heads (husbands, or wives in case of absence of husbands) who completed the survey interview. As shown in Table 1, the mean age of husbands was $44.1 \pm 13.4$ years, whereas for wives was $36.2 \pm 11.8$ years. The mean family size was $4.3 \pm 1.6$ persons. The mean monthly income was $931.1 \pm 531.1$. Egyptian pounds.

Illiterate persons accounted for $42.5 \%$ of the total (39.1\% among males and $53.7 \%$ among females). Only $4.5 \%$ of the households got a university grade $(5.6 \%$ among males and $0.7 \%$ among females). The main job was handicraft work or vendors $(58.0 \%)$. Most adult females were housewives. Approximately $6.1 \%$ of the household heads were working as farmers. The rate of unemployment among respondents (males or females) was $2.0 \%$.

Matrix (A) showed red colour cells for safety of drinking water, interruption of water supply, connection to public drainage sewers, illiteracy rate, average monthly income per person and male tobacco smoking. Yellow colour was given to the percent of houses connected to water piped system and skilled birth attendance. Good performance was observed for fully vaccination of infants, unemployment rate and voter participation. The percentage of female overweight or obesity was close to the national figures (green colour) while the percentage of male overweight /obesity was slightly higher than the corresponding national figures (yellow colour).

Matrix (A) Core Indicators: Health Determinants: Comparison between Urban HEART Indicators in Gezerit El Warak and national figures

\begin{tabular}{|c|c|c|c|}
\hline Domain & Core Indicator & $\begin{array}{c}\text { Current Survey } \\
\text { in Gezerit El Warak (\%) }\end{array}$ & National Figure* \\
\hline \multirow{4}{*}{$\begin{array}{l}\text { Physical Environment } \\
\text { and Infrastructure }\end{array}$} & Connect to piped water & 84.0 & 98.0 \\
\hline & Water safety for drink & 17.4 & 95.0 \\
\hline & $\%$ of Water supply interrupted & 100.0 & 25.7 \\
\hline & $\begin{array}{l}\text { Connect to drainage } \\
\text { public sewers }\end{array}$ & 0.0 & 56.0 \\
\hline \multirow{9}{*}{ Social and Human development } & Illiteracy rate & 42.5 & 25.2 \\
\hline & Fully immunized Infants & 95.1 & 91.7 \\
\hline & Skilled Birth Attendance & 72.2 & 78.9 \\
\hline & $\begin{array}{l}\text { Prevalence of Male } \\
\text { tobacco smoking }\end{array}$ & 56.0 & 43.9 \\
\hline & Female Over weight & 345 & 384 \\
\hline & Female Obesity & 38.0 & 39.6 \\
\hline & Male Over weight & 36.7 & 34.3 \\
\hline & Male Obesity & 21.1 & 18.2 \\
\hline & Unemployment & 2.0 & $11.9^{\mathrm{a}}$ \\
\hline Economics & Average income /month/person & 216.5 & $591.7^{\mathrm{a}}$ \\
\hline Governance & $\begin{array}{l}\text { Voter Participation } \\
\text { (Last Referendum }\end{array}$ & 52.7 & $41.0^{\mathrm{b}}$ \\
\hline
\end{tabular}

*= Egypt Demographic and Health Survey, 2008

Other sources: $a=$ CAPMAS, $b=$ the Egyptian Cabinet of Information and Decision Support Center, 2011. 
As seen in the matrix (B); both infant mortality rate and neonatal mortality rate were performed good and slightly better than the national figures (green colour). Regarding disease-specific indicators, the prevalence of hypertension and diabetes both among males or females were higher than the corresponding national figures (red colour).

Matrix (B) Core Indicators: Health Care Outcomes: Comparison between Urban HEART Indicators in Gezerit El Warak and national figures

\begin{tabular}{|c|c|c|c|}
\hline $\begin{array}{c}\text { Domain } \\
\text { Healthcare outcomes }\end{array}$ & Core Indicator & $\begin{array}{c}\text { Current Survey } \\
\text { in Gezerit El Warak }\end{array}$ & National figures* \\
\hline \multirow[b]{2}{*}{ Summary Indicator } & $\begin{array}{c}\text { Infant Mortality } \\
\text { Rate/1000 live births }\end{array}$ & 12.0 & $25^{\#}$ \\
\hline & $\begin{array}{l}\text { Neonatal Mortality } \\
\text { Rate/1000 live births }\end{array}$ & 6.0 & $16^{\#}$ \\
\hline \multirow{4}{*}{ Disease-specific Indicator } & $\begin{array}{c}\text { Male Hypertension (\%) } \\
\geq 140 / 90\end{array}$ & 20.8 & 10.5 \\
\hline & $\begin{array}{c}\text { Female Hypertension (\%) } \\
\geq 140 / 90\end{array}$ & 19.0 & 12.8 \\
\hline & $\begin{array}{c}\text { History of Diabetes Mellitus } \\
\text { among males (\%) }\end{array}$ & 11.5 & 2.6 \\
\hline & $\begin{array}{c}\text { History of Diabetes Mellitus } \\
\text { among females (\%) }\end{array}$ & 9.6 & 4.2 \\
\hline
\end{tabular}

*= Egypt Demographic and Health Survey, 2008

\# Health Affairs of Giza/MOHP 
Table 1: Sociodemographic characteristics, tobacco smoking, history of chronic diseases, and other characteristics of households of Gezerit El Warak, 2011, Egypt

\begin{tabular}{|c|c|}
\hline Participant characteristics & Results \\
\hline Age of husbands $(\mathrm{N}=643)($ mean $\pm \mathrm{SD})$ (years) & $44.1 \pm 13.4$ \\
\hline Age of wives $(\mathrm{N}=613)($ mean $\pm \mathrm{SD})$ (years) & $36.2 \pm 11.8$ \\
\hline Family size (mean \pm SD) & $4.3 \pm 1.6$ \\
\hline Monthly income (Egyptian pounds) (mean \pm SD) & $931.0 \pm 531.1$ \\
\hline \multicolumn{2}{|l|}{ Educational level [n (\%)] } \\
\hline Illiterate & $273(42.5)$ \\
\hline Primary to secondary school & $341(53.0)$ \\
\hline University & $29(4.5)$ \\
\hline \multicolumn{2}{|l|}{ Type of job $[\mathrm{n}(\%)]$} \\
\hline Governmental employee (technical/administration) & $46(7.1)$ \\
\hline Handicraft work and vendors & $373(58.0)$ \\
\hline Housewife & $129(20.1)$ \\
\hline Farmer & $39(6.1)$ \\
\hline Retired & $34(5.3)$ \\
\hline Others & $9(1.4)$ \\
\hline Not working & $13(2.0)$ \\
\hline \multicolumn{2}{|l|}{ Tobacco smoke $[\mathrm{n}(\%)]$} \\
\hline Husbands & $351(56.0)$ \\
\hline Wives & $1(0.2)$ \\
\hline \multicolumn{2}{|l|}{ Current chronic diseasesa among heads of households ${ }^{a}[\mathrm{n}(\%)]$} \\
\hline Heart diseases & $25(3.9)$ \\
\hline Viral hepatitis C & $19(3.0)$ \\
\hline Cancer & $3(0.5)$ \\
\hline Renal failure & $9(1.4)$ \\
\hline \multicolumn{2}{|l|}{ Participation in the last referendum $[\mathrm{n}(\%)]$} \\
\hline Husbands $(\mathrm{N}=627)$ & $390(62.2)$ \\
\hline Wives $(\mathrm{N}=622)$ & $268(43.1)$ \\
\hline
\end{tabular}

${ }^{a}$ History of diagnosis by a doctor or other health professionals and used medications.

\section{DISCUSSION}

Urban HEART aims to equip policy makers with the necessary evidence on which to base strategies to reduce intercity and intracity health inequities. Egypt as a member in Eastern Mediterranean Region was among the countries that implemented the Urban HEART at the first phase of program implementation.

To assess the health equity in Gezerit El Warak district, two sets of indicators were used (health outcomes and social determinants) and then compared with the national indicators. The health outcome indicators are indicative of the major outcomes or effects of multiple factors and drivers in the performance of the health system and other sectors associated with the determinants of health. Social and environmental determinants are practical approach to reduce health inequity. Furthermore, social determinants underlie most health behaviors, risks, and outcomes ${ }^{[10]}$.
Regarding the results of health determinants in the study area, physical environment and infrastructure are the worst indicators, as all houses in this slum area are not connected to drainage public sewers and less than one-fifth of houses drink safe water, although four of every five houses are connected to piped water system.

Moreover, all houses complain of interrupted water supply. Almost in the majorities of low- and low-middleincome countries, slums are not officially recognized by municipalities, or local authorities, and are therefore not included in planning or aid considerations. Unsanitary life in slum areas, as reported in many developing countries, creates major problems and adverse health effects such as increasing in mortality rates and morbidities of communicable, noncommunicable, and reproductive diseases as well lower life expectancy ${ }^{[12-14]}$. 
Regarding the indicators of social and human development, the results showed a higher rate of illiteracy among household dwellers when compared with the national figure. Illiteracy is one of the sociodemographic characteristics of urban slum dwellings in Egypt ${ }^{[4,6]}$ and other developing countries, as it is related to the poverty and cultural situation ${ }^{[8]}$. The results showed very low monthly income of the households, which is a sign of absolute poverty $(<1$ USD income per person per day; the exchange rate for one \$US=7.5 L.E. at the time of the survey).

The prevalence of tobacco smoking among males showed a higher proportion compared with the corresponding national figure. Moreover, the prevalence of tobacco smoking among males in this study was much higher than that reported in other studies conducted in slum areas in India, Peru, Nepal, and Kenya ${ }^{[15-18]}$.

The MOHP in Egypt established a primary healthcare center inside this disadvantaged area, with available complete services of maternal and child healthcare. In addition to the primary healthcare center, there are few private and NGOs clinics. Overall, most of households had accessed the public primary healthcare center to get their preventive services as it is free of charge; however, private clinics were considered the preferable place for curative services, in particularly at evening times. Therefore, the current results revealed a good coverage of infant immunization. Similar results were reported in Cambodia ${ }^{[19]}$

Most adult males were engaged in handicraft jobs. That is why the unemployment rate was low in this study. For governance indicator, we selected voting for the last constitutional referendum; the results showed a positive attitude for participation. This attitude of the Egyptian population toward voting was much improved after Arab Spring revolution. One of the main reasons of nonparticipation was not holding national identification card.

In this study, both infant and neonatal mortality rates were lower than the national figures. This may be attributed to the high vaccination coverage among children in the study area, as well as the availability of both governmental family healthcare center and private clinics, and some charity healthcare facilities provided by religious organizations. These services provided antenatal care, and about three-quarters of women were delivered under supervision of a skilled birth attendant. According to the literature review, there was no consensus of higher child mortality rates in urban slum compared with urban areas. Some studies reported that living in a slum neighborhood was associated with high infant mortality irrespective of individual and household characteristics, and this risk was attenuated among children born to women who had received antenatal care from a health professional ${ }^{[20]}$. The results of another study suggested that it may not be necessarily the place of residence that matters for child survival but, rather, access to services and economic opportunities ${ }^{[21]}$. In contrary, other studies reported high child mortality among children living in slum areas compared with those living in urban areas ${ }^{[22,23]}$.

The prevalence of hypertension among either males or females was considered high in comparison with the national figures. Our results were in agreement with other studies in slum areas in India, Nepal, and Nigeria, where they reported high prevalence of hypertension ${ }^{[15,17,18,24]}$. Similar to the high prevalence of hypertension in this study, history of diabetes mellitus was high among both males and females, a figure that exceeds markedly the national figure. In this study, a high prevalence of diabetes was reported. The occurrence of diabetes among urban slum residents may be attributed to eating behavior, low physical activities, and smoking cigarettes ${ }^{[18]}$. Depending on the history of morbidity among households is not an accurate estimate.

Based on the study results, the major problems identified were high prevalence of tobacco consumption among males, high adult illiteracy rate, residents' with no national identification card, high prevalence of hypertension, diabetes, inadequate sewage disposal, lack of safe drinking water, and finally, difficultly in access to transportation.

One of the benefits of using Urban HEART tool is the response part. Response activities followed the workshop included improving the transportation to the island through the purchase of a new ferry by the governor, establishment (under way) of two workstation for water purification, and implementation of sanitary and solid waste disposal facilities by the Governer and selected nongovernmental organizations. In addition, tobacco control activities were introduced by the nongovernmental organizations, health volunteers, and the tobacco control unit in the MOHP. Searching for people without national ID was conducted by local nongovernmental organizations. Necessary logistical support was provided to the health center in the area, and patients were screened for noncommunicable diseases, with a family folder developed for each patient.

\section{LIMITATIONS}

In this study, some morbidities and behavioral risk factors (e.g. tobacco smoking) are self-reported, and thus are subject to measurement bias. Moreover, this study was done in 2011, but we compared the results with the national data available using mainly DHS in 2008.

\section{CONCLUSION AND RECOMMENDATION}

The main health determinant inequity (lower performance) encountered in the study area was the physical infrastructure. Moreover, there were higher 
percentages of hypertension, tobacco smoking, and history of diabetes mellitus compared with the national figures. Other health determinants were close to the national figures, which indicate that not all urban slum areas need the same interventions for upgrading and improvement of the health status of their dwellings. There should be a tailored intervention program for each slum or disadvantage area according to the assessment of its health determinants. The benefit of applying Urban HEART tool was the immediate response from governmental authorities and NGOs and the involvement of local community to reduce their health inequity.

Steps taken toward sustainability include ensuring community participation at all stages of planning, implementation, and monitoring. Dissemination of this successful experience to other areas is recommended.

\section{CONFLICT OF INTEREST}

There are no conflicts of interest.

\section{ACKNOWLEDGMENT}

The authors acknowledge Dr Naeema Al-Gasseer and Dr Mona Abo Naga from EMRO/Country Office for providing oversight into the research. Special thanks to the local community team at Geziret El Warak who devoted their time and efforts during preparation of the research protocol and their support during field work.

This study was funded by WHO-EMRO, WR Office/ Egypt. Community-Based Initiative. PO200451033.

\section{REFERENCES}

1. United Nations Population Fund (UNFPA). State of world population, 2007. Unleashing the potential of urban growth. [Accessed March 2015]. Available at: https://www.unfpa.org/sites/ default/files/pub-pdf/695_filename_sowp2007_ eng.pdf.

2. UN Habitat. The Challenge of slums: Global report on human settlements, 2003. [Accessed February 2015]. Available at: http://www.unhabitat.org/ downloads/docs/GRHS.2003.2.pd.

3. Khalifa MA. Redefining slums in Egypt: unplanned versus unsafe areas. Habitat Int 2011; 35:40-49.

4. UNICEF and Informal Settlements Development Facility (ISDF), Egypt (2013). Multidimensional child poverty in slums and unplanned areas in Egypt, UNICEF Egypt and ISDF. [Accessed June 2016]. Available at: https://www.unicef.org/egypt/ eg_UNICEF_ISDF_2013_Child_poverty_in_ slums_English.pdf.
5. Khadr Z. Monitoring socioeconomic inequity in maternal health indicators in Egypt: 1995-2005. Int J Equity Health 2009; 8:38-49.

6. Kharboush IF, Ismail HM, Kandil AA, Mamdouh HM, Muhammad YY, El Sharkawy OG, et al. Raising the breast health awareness amongst women in an urban slum area in Alexandria, Egypt. Breast Care 2011; 6:375-379.

7. Kimani-Murage EW, Ngindu AM. Quality of water the slum dwellers use: the case of a Kenyan slum. J Urban Health 2007; 84:829-838.

8. Joshi A, Prasad S, Kasav JB, Segan M, Singh AK. Water and sanitation hygiene knowledge attitude practice in urban slum settings. Glob J Health Sci 2013; 6:23-34.

9. Turley R, Saith R, Bhan N, Rehfuess E, Carter B. Slum upgrading strategies involving physical environment and infrastructure interventions and their effects on health and socio-economic outcomes. Cochrane Database Syst Rev 2013; $1: 1-4$.

10. World Health Organization (WHO). Urban HEART: Urban Health Equity Assessment and Response Tool, WHO Center for Health Development, Kobe, 2010. [Accessed 2011, May, 14]. Available from: http://www.who.int/kobe centre/publications/urban_heart/en/

11. El-Zanaty F, Way AA. Egypt Demographic and Health Survey, 2008. [Accessed January 2015]. Available at: http://dhsprogram.com/pubs/pdf/ fr220/fr220.pdf.

12. Bocquier P, Beguy D, Zulu EM, Muindi K, Konseiga A, Yé Y. Do migrant children face greater health hazards in slum settlements? evidence from Nairobi, Kenya. J Urban Health 2011; 88(Suppl 2):266-281.

13. Anand K, Shah B, Yadav K, Singh R, Mathur P, Paul E, et al. Are the urban poor vulnerable to noncommunicable diseases? a survey of risk factors for non-communicable diseases in urban slums of Faridabad. Natl Med J India 2007; 20:115-120.

14. Szwarcwald CL, da Mota JC, Damacena GN, Pereira TG. Health inequalities in Rio de Janeiro, Brazil: lower healthy life expectancy in socioeconomically disadvantaged areas. Am J Public Health 2011; 101:517-523.

15. Acharyya T, Kaur P, Murhekar MV. Prevalence of behavioral risk factors, overweight and hypertension in the urban slums of North 24 
Parganas District, West Bengal, India , 2010. Indian J Public Health 2014; 58:195-198.

16. Heitzinger K, Montano SM, Hawes SE, Alarcón JO, Zunt JR. A community-based cluster randomized survey of non-communicable disease and risk factors in a peri-urban shanty town in Lima, Peru. BMC Int Health Hum Rights 2014; $14: 19$.

17. Oli N, Vaidya A, Thapa G. Behavioral risk factors of non-communicable diseases among Nepalese urban poor: a descriptive study from a slum area of Kathmandu. Epidemiol Res Int 2013; 2013:1-17.

18. 18. Ayah R, Joshi MD, Wanjiru R, Njau EK, Otieno CF, Njeru EK, et al. A population-based survey of prevalence of diabetes and correlates in an urban slum community in Nairobi, Kenya. BMC Public Health 2013; 13:371.

19. Soeung SC, Grundy J, Sokhom H, Blanc DC, Thor $\mathrm{R}$. The social determinants of health and health service access: an in depth study in four poor communities in Phnom Cambodia. Int $\mathrm{J}$ Equity Health 2012; 11:46-55.
20. Kyu HH, Shannon HS, Georgiades K, Boyle $\mathrm{MH}$. Association of urban slum residency with infant mortality and child stunting in low and middle income countries. Biomed Res Int 2013; 2013:604974

21. Bocquier P, Madise NJ, Zulu EM. Is there an urban advantage in child survival in sub-saharan Africa? evidence from 18 countries in the 1990s. Demography 2011; 48:531-558.

22. Kimani-Murage EW, Fotso JC, Egondi T, Abuya B, Elungata $\mathrm{P}$, Ziraba AK, et al. Trends in childhood mortality in Kenya: the urban advantage has seemingly been wiped out. Health Place 2014; 29:95-103.

23. Islam MM, Azad KM. Rural-urban migration and child survival in urban Bangladesh: Are the urban migrants and poor disadvantaged? J Biosoc Sci 2008; 40:83-96.

24. Daniel OJ, Adejumo OA, Adejumo EN, Owolabi RS, Braimoh RW. Prevalence of hypertension among urban slum dwellers in Lagos, Nigeria. J Urban Health 2013; 90:1016-1025. 